\title{
Conformation Dependent Mutation Detection
}

National Cancer Institute

\section{Source}

National Cancer Institute. Conformation Dependent Mutation Detection. NCI Thesaurus. Code C20064.

Polymorphism, single-stranded conformational, detection. Altered migration of singlestranded DNA molecules in non-denaturing gels based upon 3-D conformation. Uses PCR and/or restriction enzymes to generate short dsDNA molecules spanning a sequence of interest. The dsDNA molecules are heat denatured, and then quickly cooled. Each ssDNA molecule will assume a secondary structure (conformation) dependent upon its unique sequence. Base mutations will often result in altered conformations, with altered mobilities, which can be visualized following separation in non-denaturing gels. $(\mathrm{NCl} / \mathrm{OSP})$ 